\title{
Unexpected recent records of twaite shad (Alosa fallax) in two North-eastern Iberian rivers: recolonization or recovery of remnant populations?
}

\author{
Miquel Àngel Fuentes ${ }^{1, *}$, Iscle Martínez-Roigen 2 Quim Pou-Rovira ${ }^{1,3}$ and Enric Aparicio ${ }^{1}$ \\ ${ }^{1}$ GRECO, Institute of Aquatic Ecology, University of Girona, 17003 Girona, Catalonia, Spain. \\ 2 Carrer Nou 106b, 17100 La Bisbal, Catalonia, Spain. \\ ${ }^{3}$ Sorelló, estudis al medi aquàtic, Pl. St. Pere 15 baixos, 17007 Girona, Catalonia, Spain. \\ * Corresponding author: miguelangelfuentesrosua@gmail.com
}

Received: $22 / 10 / 18$

Accepted: 01/07/19

\begin{abstract}
Unexpected recent records of twaite shad (Alosa fallax) in two North-eastern Iberian rivers: recolonization or recovery of remnant populations?

The presence of twaite shad Alosa fallax (Lacépède, 1803), an anadromous fish that migrates to lower and middle river reaches to spawn, has been reported in the Fluvià and Ter rivers (NE Spain) after several decades of absence of confirmed records. From 2015 to 2017 a total of 32 specimens, including one juvenile fish, were captured by angling in the River Fluvià, and a single individual was captured in the River Ter. The origin of these fish in the Fluvià may be the recovery of a scarce local population that remained undetected or a recolonization by individuals straying from neighbouring populations. The presence of a single individual in the Ter and the absence of records for over a century in this river suggest that this specimen may have come from a nearby population. If the establishment of a twaite shad population in the Fluvià is confirmed in the next few years, the construction of fish passages would increase the availability of spawning habitats and improve the species' conservation prospects.
\end{abstract}

Key words: Clupeidae, homing behaviour, straying behaviour, resilience, anadromous fishes, conservation

\section{RESUMEN}

Citas recientes inesperadas de saboga (Alosa fallax) en dos ríos del Noroeste de la Península Ibérica: ¿recolonización o recuperación de poblaciones remanentes?

La presencia de saboga Alosa fallax (Lacépède, 1803), un pez anádromo que migra a los tramos bajos y medios de los ríos para desovar, se cita en los ríos Fluvià y Ter (NE de España) después de varias décadas de ausencia de registros confirmados. De 2015 a 2017, un total de 32 especimenes fueron capturados en el río Fluvià, incluyendo un juvenil, y un individuo en el río Ter. El origen estos peces podría ser la recuperación de una escasa población local que habría permanecido sin ser detectada, pero también existe la posibilidad de una recolonización de individuos errantes procedentes de poblaciones vecinas. La presencia de un solo individuo en el Ter, junto con la ausencia de citas por más de un siglo en este río, sugiere que el espécimen puede proceder de una población vecina. Si se confirma en los próximos años la presencia de una población estable de saboga en el Fluvià, la construcción de pasos de peces aumentaria la disponibilidad de hábitats de freza y podría mejorar sus perspectivas de conservación.

Palabras clave: Clupeidae, instinto de regresar a casa, comportamiento de extravio, resiliencia, peces anádromos, conservación 


\section{INTRODUCTION}

The twaite shad Alosa fallax (Lacépède, 1803) is an anadromous fish species of the family Clupeidae that has a pelagic sea life and migrates to lower and middle river reaches to spawn, although some landlocked populations also exist (Aprahamian et al., 2003a). The timing of the spawning migration of adults into freshwaters occurs in spring. Mature fish shoal during the day along the shore of the river and spawning takes place at night. After hatching, juveniles migrate to downstream river reaches and to estuaries during summer and autumn and enter the sea at the beginning of winter (Aprahamian et al., 2003a).

Genetic differences between populations suggest that most individuals return to their natal rivers to spawn (a phenomenon called homing behaviour) but also that some exchange between neighbouring populations occurs because of strayed individuals (individuals who enter a river other than their natal river) (Jolly et al., 2012). A recent study carried out in the northwest of the Iberian Peninsula by studying the microchemistry of otoliths showed that the exchange of straying individuals between nearby populations can be considerable (Nachón, 2016).

The range of twaite shad extends along the Atlantic coasts and rivers from southern Norway to Morocco, and eastwards into the Mediterranean Sea. Several sub-species of anadromous twaite shad have been described based on varying numbers of gill rakers and geographic distribution (Hoestlandt, 1991). Of these, three are present in the Mediterranean: A. fallax rhodanensis (Roule, 1924 ) is found along the European coast of the western Mediterranean; A. fallax algeriensis (Regan, 1916) is distributed along the western Mediterranean coast of North Africa; and $A$. fallax nilotica (Geoffroy Saint-Hilaire, 1808) is found in the eastern Mediterranean from Italy to River Nile (Aprahamian et al., 2003b). However, the systematics of these sub-species is a matter of debate and Kottelat (1997) suggested that until taxonomy is resolved the three subspecies should be classified as $A$. fallax.

In the western Mediterranean, the most important populations remains in the largest rivers in the region, i.e. the Rhône and the Ebro (Le Corre et al., 1997; López et al., 2007) though it is also present in the Têt, Agly, Aude and Hérault rivers (Le Corre et al., 2000; Mutel et al., 2017). In this area, some twaite shad populations were in sympatry with populations of the other anadromous European shad species, the allis shad Alosa alosa (Linnaeus, 1758). This latter species is currently considered absent in the Mediterranean (Le Corre et al., 2005), but some populations of twaite shad show genetic variation typical of allis shad, suggesting that introgressive hybridization between these two species occurred at some stage (Faria et al., 2012; Sotelo et al., 2014). During the $20^{\text {th }}$ century, the impact of human activities has led to a considerable decline in abundance of European shads throughout their distribution range. Construction of dams that block access to their spawning grounds, water pollution and overfishing are among the main factors that have impacted negatively on its populations (Elvira, 1995; Baglinière, 2000; Aprahamian et al., 2003b). As a consequence, shads are now under protection at different levels, from international level, through the state level of each country and in Spain to autonomous community level (Aprahamian et al., 2003a; Perea et al., 2011).

The presence of twaite shad in the Mediterranean coastal area of Spain was documented in the main rivers draining this region, namely the Ebro, Llobregat, Ter and Fluvià (Llatjós, 1946; Nadal, 1981; Sostoa \& Lobón-Cerviá, 1989; Sostoa et al., 1994). Its populations suffered a dramatic decline in both abundance and distribution, to the point of a presumed extirpation from all previously occupied basins (Aparicio et al., 2000; López et al., 2007). However, in the Ebro the twaite shad was detected again in 2004 and since then its numbers have increased substantially, suggesting an ongoing recovery of this population (López et al., 2007, 2011). In the three other watersheds, fish samplings performed in the 1990s (Moreno-Amich et al., 1999; Aparicio et al., 2000) and 2000s (Pou-Rovira et al., 2004, 2007; Maceda-Veiga et al., 2010; Aparicio et al., 2013) showed no presence of the species. The last recorded presence of twaite shad corresponded to the River Fluvià in the 1980s (Sostoa et al., 1994). Since the lower course of the Fluvià potentially maintains sufficient habitat to support twaite shad reproduc- 

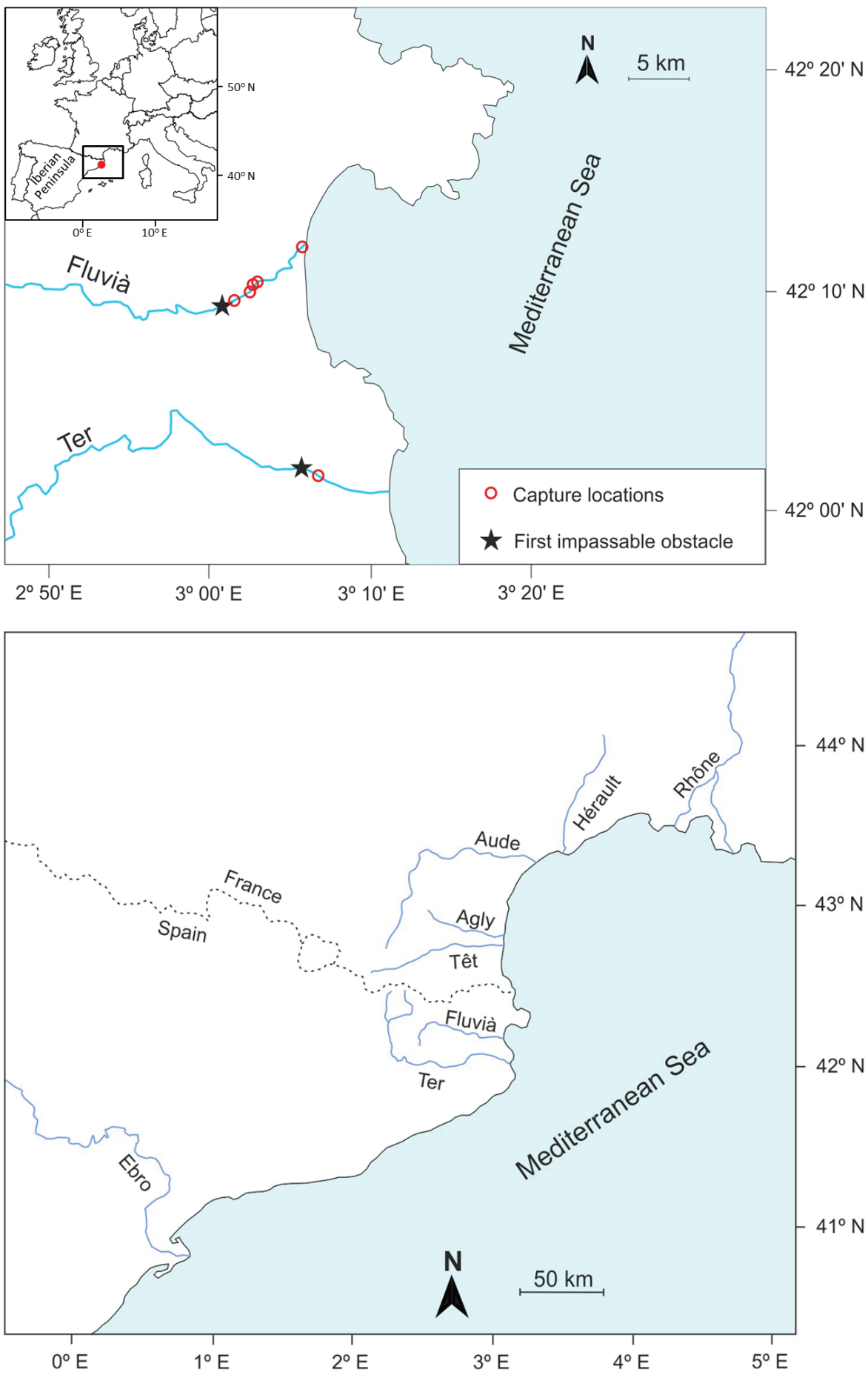

Figure 1. (Top) Map of the study area showing the capture locations of twaite shad (Alosa fallax) specimens in the Fluvià and Ter rivers from 2015 to 2017 and the location of the first impassable obstacle in each river, and (bottom) map of the Western Mediterranean area showing the main rivers where populations of twaite shad have been reported in recent times (see text for references). (Arriba) Localidades de captura de los especímenes de saboga (Alosa fallax) en los ríos Fluvià y Ter entre 2015 y 2017 y la ubicación del primer obstáculo impasable en cada río, y (abajo) mapa del Mediterráneo Occidental mostrando los principales ríos en los que se han reportado poblaciones de saboga en tiempos recientes (ver texto para referencias). 
tion (clean gravel beds, resting pools, good water quality; ACA, 2013), the aim of the work was to investigate whether the species were still present. The objective of this paper was to discuss the possible recovery of a twaite shad population in the Fluvià River as well as the possible origin of the captured individuals. We also present data of one adult twaite shad specimen captured in the River Ter after over a century of absence.

\section{METHODS}

The study area included the rivers Fluvià $(97 \mathrm{~km}$ in length, mean flow of $\left.1.27 \mathrm{~m}^{3 / \mathrm{s}}\right)$ and Ter $(208$ $\mathrm{km}$ in length, mean flow of $26.79 \mathrm{~m}^{3} / \mathrm{s}$ ) in Catalonia (NE Spain). The potential habitat is restricted to 8 and $6 \mathrm{~km}$ respectively, because of the presence of the first insurmountable obstacle (Fig. 1).

Surveys consisted of a combination of visual methods and angling with rod and reel, which was considered suitable for the objectives of the study and offers a considerable reduction in field effort relative to other sampling methods (Côté \& Perrow, 2006). Moreover, twaite shad is difficult to catch by conventional scientific fishing techniques such as electrofishing. This technique is best suited to small, wadeable streams, but in medium-sized rivers, physical habitat limitations (i.e. water depth and river width) can hinder effective sampling (Favrot \& Kwak, 2016). Surveys were conducted during the period of natural upstream migration of twaite shad (i.e. the spring months) and during the downstream juvenile migration period (i.e. late summer, autumn). Bankside visual surveys were possible due to high water transparency and are appropriate during the spawning period when the presence of aggregations of fish may be identified. Observers wore polarised sunglasses to reduce glare and improve fish spotting. Hook-and-line angling was carried out after these visual surveys. This method is highly selective and is therefore not suitable for sampling the entire fish community, but can be a cost-effective method of sampling specific species. To reduce the risk of incidental mortality by hook damage, all survey angling was done with artificial lures carrying simple barbless hooks, which are less intrusive. Lure size was adapted to fish size depending on the season and location, using smaller lures near the river mouth in late summer, where juvenile individuals were expected, than those used upstream in spring for adult fish. Fish captured were measured (fork length, cm), photographed and released as soon as possible to minimize stress. The photographs were later used for the identification of the species according the diagnostic characters of twaite shad: less than 60 scales along the midline (vs. 60-90 in allis shad), less than 20 transverse scale rows (vs. 20-26 in allis shad), regular scaling on the longitudinal line (as opposed to irregular scaling in allis shad) (Aprahamian et al., 2003b). The number of gill rakers on the first gill arch, which is the main discriminating character for identifying Alosa species (Aprahamian et al., 2003 b), could not be analyzed since it would have required the sacrifice of the fish.

Visual surveys and angling were conducted from 2008 to 2017 within the potential habitat for twaite shad, i.e. downstream of the first obstacle to migration (Fig. 1). Sampling effort varied over this period; the number of survey days per year in both Ter and Fluvià was between 2 and 10 before 2014, and a fixed 6 days from 2014 to 2017.

\section{RESULTS}

First visual detection of fish resembling shads occurred in May 2015, and some of them were later captured by angling. Captured fish were identified as twaite shad (Fig. 2) by the following characters: scales along the midline (mean: $57.5 \pm$ 2.26 SD), transverse scale rows (mean: $18.0 \pm 1.2$ SD) and regular scaling on the longitudinal line (Aprahamian et al., 2003b).

Overall, a total of 31 adult specimens (size range: $35-50 \mathrm{~cm}$ fork length) were captured by angling in the Fluvià between April and June from 2015 to 2017 (Fig. 1). An additional juvenile specimen (size: $10 \mathrm{~cm}$ fork length) was captured in the Fluvià estuary in October, 2016. Also, in May 2015, an individual (size range: $40-50 \mathrm{~cm}$ ) was found in the Ter (Fig. 1).

\section{DISCUSSION}

Despite the absence of the main diagnostic character (gill raker count), the combination of the 

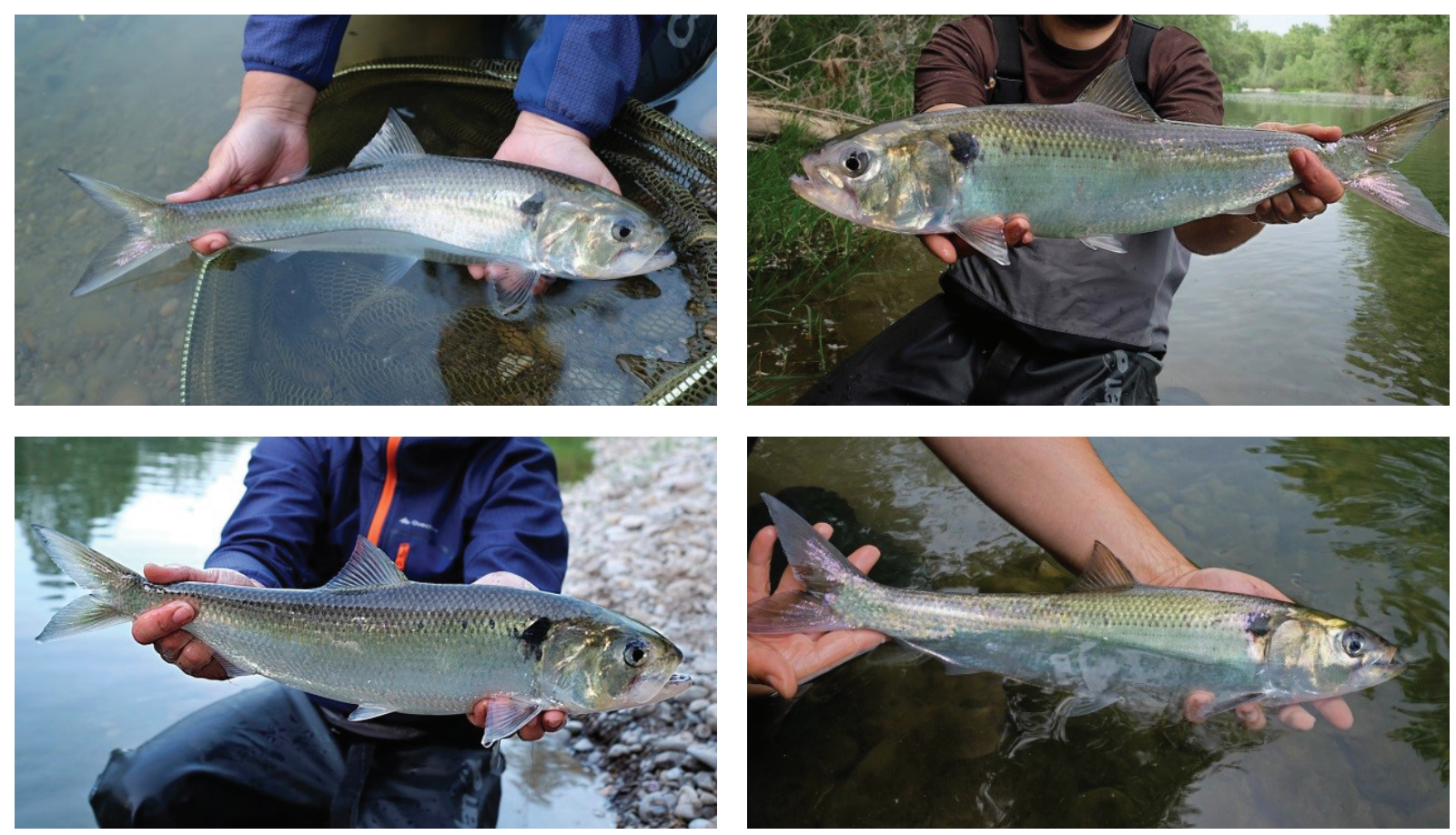

Figure 2. Adult specimens of twaite shad (Alosa fallax) captured by angling in the River Fluvià on May, 2015. Ejemplares adultos de saboga (Alosa fallax) pescados con caña en el río Fluvià en mayo de 2015.

other diagnostic morphological characters allowed us to identify the shad individuals captured in the Fluvià and Ter rivers as twaite shad. However, hybridization between twaite shad and allis shad has been reported over most of their historical range (Alexandrino et al., 2006; Coscia et al., 2010; Jolly et al., 2012), including the Western Mediterranean (Rhône and Ebro rivers) (Andree et al., 2011; Faria et al., 2012; Sotelo et al., 2014). For example, $34 \%$ of individuals collected in a study in the Ebro presented typical allis shad mitochondrial haplotypes despite being morphologically classified as twaite shad (Sotelo et al., 2014). Therefore, without genetic analysis, the possibility that some fish from the Fluvià are hybrid individuals is feasible and should be clarified in subsequent studies.

The origin of the twaite shad detected in the Fluvià is uncertain. The first possibility is that they come from the recovery of a local population that persisted at very low or residual levels for years and remained undetected, as reported in other rivers such as the Ebro (Sotelo et al., 2014).
Another possibility is that the current population originated through recent recolonization by strays from neighbouring populations. It has been suggested that twaite shad displays a high fidelity to breeding grounds, based on the pattern of genetic isolation by distance on a regional scale, but some migration between neighbouring populations also occurs (Jolly et al., 2012). For example, a recent study carried out in the Northwest of the Iberian Peninsula determined that the degree of exchange of strayers can be substantially high (around $30 \%$ ) between two relatively close populations (barely $100 \mathrm{~km}$ distance between the two rivers; Nachón, 2016). There are six twaite shad populations that could provide straying individuals within a radius of $290 \mathrm{~km}$, in the Têt, Agly, Aude, Hérault and Rhône rivers to the north (Le Corre et al., 2000; Mutel et al., 2017), and the Ebro to the south (López et al., 2007) (Fig. 1). Further genetic research based on the distinctive genetic composition between different Mediterranean populations (Le Corre et al., 2005; Sotelo et al., 2014) would clarify the origin of the twaite 
shad in the Fluvià. The microchemistry of otoliths could also help in unravelling the origin of individuals and the exchange between nearby twaite shad populations (Nachón, 2016).

Although the species identity of the juvenile captured in the Fluvià estuary could not be confirmed, it is highly probable that this specimen would be a twaite shad given the results of this study and the context of shad populations in the Mediterranean basin, where there are no other shad species populations in the nearby rivers. This suggests possible successful reproduction in this river. However, given the plasticity of shad individuals during this phase (Taverny et al., 2000; Magath et al., 2013; Nachón, 2016) and the proximity of the sea, its provenance from another nearby population cannot be excluded. The isolated presence of a single individual in the Ter and the absence of records for over a century in this river suggest that this specimen may have come from a nearby population. However, it is necessary to monitor this river to demonstrate whether it was only an erratic individual or whether a small population is establishing itself there.

The reappearance of the twaite shad in the River Fluvià chimes with the positive trend of the species' recovery observed in other European rivers in recent years, both in the Atlantic (Maes et al., 2008; Magath \& Thiel, 2013) and in the Mediterranean (Lebel et al., 2001; López et al., 2007). If the establishment of a twaite shad population in the Fluvià is confirmed in the next few years, the construction of fish passages would improve its conservation prospects by allowing fish to migrate further upstream and so increase the availability of spawning and nursery habitats.

\section{ACKNOWLEDGEMENTS}

We thank Javier Díaz, Fabien Forget and Victor Nicolás for their information and their help with the field work and David Butterfield for reviewing the manuscript.

\section{REFERENCES}

ACA (CATALAN WATER AGENCY). 2013. Memòria tècnica del Programa de Seguiment $i$ Control (PSiC) del Districte de Conca Fluvial de Catalunya (Monitoring and control program of the Catalan River Basin District). Agència Catalana de l'Aigua, Departament de Territori i Sostenibilitat, Barcelona. 108 p.

ANDREE, K. B., M. ANGEL LOPÉZ, P. ALEXANDRINO, R. FARIA \& E. GISBERT. 2011. A preliminary genetic analysis of a recently rediscovered population of the Twaite shad (Alosa fallax) in the Ebro river, Spain (Western Mediterranean). Journal of Applied Ichthyology, 27: 21-23. DOI: 10.1111/j.14390426.2011.01847.x

APARICIO, E., M. J. VARGAS, J. M. OLMO \& A. DE SOSTOA. 2000. Decline of native freshwater fishes in a Mediterranean watershed on the Iberian Peninsula: a quantitative assessment. Environmental Biology of Fishes, 59: 11-19. DOI: 10.1023/A:1007618517557

APARICIO, E., G. CARMONA-CATOT \& C. ALCARAZ. 2013. Les poblacions de peixos en els estuaris del Ter i del Daró. In: Col·lecció Recerca i Territori, 5: 143-232. Museu de la Mediterrània \& Parc Natural del Montgrí, les Illes Medes i el Baix Ter, Girona.

APRAHAMIAN, M. W., J. L. BAGLINIÈRE, M. R. SABATIÉ, P. ALEXANDRINO, R. THIEL \& C. D. APRAHAMIAN. 2003a. Biology, status, and conservation of the anadromous Atlantic twaite shad Alosa fallax fallax. American Fisheries Society Symposium, 35: 103-124.

APRAHAMIAN, M. W., C. D. APRAHAMIAN, J. L. BAGLINIÈRE, M. R. SABATIÉ, \& P. ALEXANDRINO. 2003b. Alosa alosa and Alosa fallax spp. Literature Review and Bibliography. R\&D Technical Report W1-014/TR: $349 \mathrm{pp}$.

BAGLINIÈRE, J. L. 2000. Le genre Alosa sp. In: Les aloses (Alosa alosa et Alosa fallax spp.): écobiologie et variabilité des populations. J.L. Baglinière, P. Elie (eds.): 1-32. INRA-Cemagref, Paris, France.

CÔTÉ, I. M. \& , M. R. PERROW. 2006. Chapter 5: Fish. In: Ecological census techniques: a Handbook, 2nd edition. W.J. Sutherland (ed.): 250-277. Cambridge University Press, Cambridge, UK.

ELVIRA, B. 1995. Conservation status of endemic freshwater fish in Spain. Biological 
Conservation, 72: 129-136. DOI: 10.1016/ 0006-3207(94)00076-3

FAVROT, S. D \& T. J. KWAK. 2016. Efficiency of Two-Way Weirs and Prepositioned Electrofishing for Sampling Potamodromous Fish Migrations. North American Journal of Fisheries Management, 36: 167-182. DOI: 10.1080/02755947.2015.1114537

JOLLY M. T., M. W. APRAHAMIAN, S. J. HAWKINS, P. A. HENDERSON, R. HILLMAN, O. O'MAOILÉIDIGH, P. S. MAITLAND, R. PIPER \& M. J. GENNER. 2012. Population genetic structure of protected allis shad (Alosa alosa) and twaite shad (Alosa fallax). Marine Biology, 159: 675-687. DOI: 10.1007/s00227-011-1845-x

KOTTELAT, M. 1997. European freshwater fishes. Biologia (Bratislava), 52 (Suppl. 5):1-271.

LE CORRE, M., J. L. BAGLINIÈRE, M. R. SABATIÉ, J. Y. MENELLA \& D. PONT. 1997. Données récentes sur les caractéristiques morphologiques et biologiques de la population d'Alose feinte du Rhône (Alosa fallax rhodanensis, R. 1924). Bulletin Français de la Pêche et de la Pisciculture, 346: 527-545. DOI: 10.1051/kmae:1997002

LE CORRE, M., M. R. SABATIÉ \& J. L. BAGLINIĖRE. 2000. Caractérisation démographique des populations d'Alosa fallax rhodanensis (Roule, 1924) (Clupeidae) de la méditerranée française. Cybium, 24: 119-128.

LE CORRE, M. , P. ALEXANDRINO, M. R. SABATIÉ, M. W. APRAHAMIAN \& J. L. BAGLINIÈRE. 2005. Genetic characterisation of the Rhodanian twaite shad, Alosa fallax rhodanensis. Fisheries Management and Ecology, 12: 275-282. DOI: 10.1111/j. 1365-2400.2005.00451.X

LEBEL I., J. Y. MENELLA \& M. LE CORRE. 2001. Balance sheet of the migratory fish program actions for the twaite shad population (Alosa fallax rhodanensis) on the Rhone-Mediterranean-Corsica basin. Bulletin Français de la Pêche et de la Pisciculture, 362/363: 1077-1100. DOI: 10.1051/kmae:2001038

LÓPEZ M. A., N. GÁZQUEZ, J. M. OLMO-VIDAL, M. W. APRAHAMIAN \& E. GISBERT. 2007. The presence of anadro- mous twaite shad (Alosa fallax) in the Ebro river (Western Mediterranean, Spain): an indicator of the population's recovery? Journal of Applied Ichthyology, 23: 163-166. DOI: 10.1111/j.1439-0426.2006.00797.x

LÓPEZ, M. A., K.B. ANDREE, R. SÁNCHEZ, J. M. QUERAL, N. FRANCH, P. SCHNEIDER \& E. GISBERT. 2011. First characterization of the spawning habitat and mating behaviour of Twaite shad in the Ebro River (Western Mediterranean). Journal of Applied Ichthyology, 27: 53-55. DOI: 10.1111/j.14390426.2011.01852.x

LLATJÓS, J. 1946. Los ríos y la pesca fluvial en la provincia de Barcelona (Datos y rutas de pesca). Publicaciones de la Federación Española de Pesca, núm. 4, Madrid. 32 p.

MACEDA-VEIGA, A. , A. MONLEON-GETINO, N. CAIOLA, F. CASALS, \& A. DE SOSTOA. 2010. Changes in fish assemblages in catchments in north-eastern Spain: biodiversity, conservation status and introduced species. Freshwater Biology, 55: 1734-1746. DOI: $10.1111 / \mathrm{j} .1365-2427.2010 .02407 . x$

MAES, J., M. STEVENS \& J. BREINE. 2008. Poor water quality constrains the distribution and movements of twaite shad Alosa fallax fallax (Lacépède, 1803) in the watershed of river Scheldt. Hydrobiologia, 602: 129-143. DOI: $10.1007 / \mathrm{s} 10750-008-9279-2$

MAGATH, V. \& R. THIEL. 2013. Stock recovery, spawning period and spawning area expansion of the twaite shad Alosa fallax in the Elbe estuary, southern North Sea. Endangered Species Research, 20: 109-119. DOI: 10.3354/esr00490

MORENO-AMICH, R., Q. POU-ROVIRA \& L. SUNYER. 1999. Atles de peixos del Parc Natural dels Aiguamolls de l'Empordà (Informe técnico). Institute of Aquatic Ecology. University of Girona. Girona, Spain.

MUTEL, M., P. CAMPTON \& I. LEBEL. 2017. Etude de faisabilité pour la mise en place d'un suivi de la population d'Aloses sur les fleuves côtiers des Pyrénées Orientales: Le Tech, la Têt et l'Agly. Campagne d'études 2016. Association Migrateurs Rhône-Méditerranée, Arles, France. 33p.

NACHÓN, D. J. 2016. Dinámica poblacional y 
microquímica de los otolitos de las poblaciones de saboga, Alosa fallax (Lacépède, 1803), de los ríos Ulla y Miño. Tesis doctoral, Universidade de Santiago de Compostela, Santiago de Compostela, España.

NADAL, J. 1981. Els nostres peixos. Diputació de Girona, Girona. 255 p.

POU-ROVIRA, Q., C. ALCARAZ, C. FEO, L. ZAMORA, A. VILA-GISPERT, Q. CAROL, E. GARCIA-BERTHOU \& R. MORENO-AMICH. 2004. Els peixos. Papers del Montgrí, 23: 71-85.

POU-ROVIRA Q., M. CLAVERO \& L. ZAMORA. 2007. Estat de conservació de l'espinós (Gasterosteus aculeatus) i de la bavosa de riu (Salaria fluviatilis) a la plana del Baix Ter. Papers del Montgrí, 28: 55-91.

SOSTOA, A. DE. \& J. LOBÓN-CERVIÀ. 1989. Fish and fisheries of the River Ebro: actual state and recent history. In: Historical changes of large alluvial rivers: Western Europe. G.E. Petts, H. Möller, A.L. Roux (eds.): 233-247.
John Wiley \& Sons Ltd., Chichester, UK. SOSTOA, A. DE, J. V. FERNÁNDEZ, F. J. DE SOSTOA \& J. CASAPONSA. 1994. Ictiofauna dels aiguamolls de L' Empordá. In: Els sistemes naturals dels Aiguamolls de l'Empordà. J. Gosálvez, J. Serra, E. Velasco (eds.): 307-327. Institució Catalana d'Història Natural, Treballs, 13, Barcelona.

SOTELO, G., K. B. ANDREE, M. A. LÓPEZ, P. ALEXANDRINO, E. GISBERT \& R. FARIA. 2014. The puzzling demographic history and genetic differentiation of the twaite shad (Alosa fallax) in the Ebro River. Conservation Genetics, 15: 1037-1052. DOI: 10.1007/s10592-014-0597-9

VOLK, J., D. BEKKEVOLD \& V. LOESCHCKE. 2007. Weak population differentiation in northern European populations of the endangered anadromous clupeid Alosa fallax. Journal of Fish Biology, 71: 461-469. DOI: 10.1111/j.1095-8649.2007. 01610.x

Con el patrocinio de:

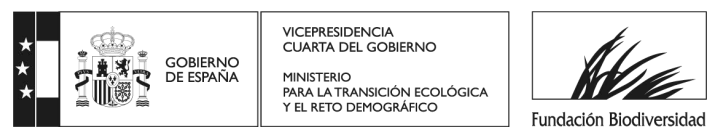

